\title{
Epidemiological and clinical features of Spanish flu in the city of Ferrara and in Italy. Containment rules and health measures adopted in the past to fight the pandemic
}

\author{
Carlo Contini' ${ }^{1}$, Chiara Beatrice Vicentini ${ }^{2}$ \\ ${ }^{1}$ Dipartimento di Scienze Mediche, Sezione di Malattie Infettive e Dermatologia, Università di Ferrara, Italy; \\ 2Dipartimento di Scienze della Vita e Biotecnologie, Sezione del Farmaco e Prodotti della Salute, \\ Università di Ferrara, Italy
}

Article received 17 April, 2021; accepted 16 July, 2021

\section{SUMMARY}

The "Spanish" flu has often been described as the "Greatest Medical Holocaust in History" and most victims were young and healthy. In Italy, as elsewhere, this pandemic influenza struck in three successive and close waves with incredible speed in a very short time. The virus first arrived in a few Italian regions and gripped the country in an epidemic clamp. When the flu hit Ferrara, the health authorities began to claim that it was no more or less like the same disease that Ferrara had also experienced in the 19th century, although the population was not very willing to believe them. Moreover, the control measures were considered by all to be extremely mild, varying only the opening hours of cinemas and pharmacies and forbidding spitting on the ground; there was no disinfection of stores and streets and the dead were left at home for three days, unlike in larger cities. In 1918-19, Ferrara did much to contain the devastating effects of the war, especially in terms of saving lives. The largest Red Cross unit in Italy, later called Ospedale Nuovo, was built. Moreover, since Ferrara was the first hospital evacuation zone, it was necessary to build other hospitals in the city's schools in addition to the already existing ones, including the famous Ospedale Militare Neurologico di Villa Seminario, which was the first Italian neuro- logical hospital of the Great War for veterans of the front line, intended for the specialised treatment of nervous disorders and psychosis caused by the war or by bombs.

We have extracted the cases of death from the Register of Deaths of the Municipality of Ferrara. During the period January 1918 - June 1919, in addition to the number of deaths due to influenza, grippe or Spanish flu we also considered influenza-related complications affecting mortality and identified seven main groups of diseases by grouping them according to morbid forms and anatomical location. According to these criteria, 1,059 deaths were attributable to influenza or related causes during January-December 1918. This partly reflects the excess of deaths in the year 1918 of 1,279 over the average for the years 1916-1919, and 1920. The largest number of deaths was attributable to bronchopneumonia and pneumonia. However, an increase in mortality from other infectious diseases such as typhoid ileus, tuberculosis, malaria and smallpox was observed during the same period until January 2019, making up the shortfall in the total number of deaths recorded.

Keywords: Spanish flu, Ferrara, COVID-19, Pandemic, $1^{\text {st }}$ World War, Prophylaxis, Register of death.
Corresponding author

Chiara Beatrice Vicentini

E-mail: vcc@unife.it

\section{INTRODUCTION}

Talking about the Spanish flu today is not easy 1 matter. The Spanish pandemic that raged between 1918 and 1920 was so called because the first to report on it were Spanish newspapers, ex- 
empt from censorship as the country was not involved in the First World War [1]. In the spring of 1918 , reports of the contagion in Spain began to spread. The illustrious victim was Spain's King Alfonso XIII. In other countries, this information was obscured.

The Spanish epidemic was given various names depending on the country and the stage of its development: "fashionable disease", "foreigner", "cursed", "capricious", "rebalancer", "catarrh lightning", "Flanders fever", "3-day fever", "Parma fever", "Bombay fever", "Singapore fever", "German", "Brazilian", "sumo flu", "big cold fever', 'southern fever', 'white man's flu', "trancazo", "black lash", "Bolshevik disease", "manhu", "Naples soldier" [2]. These are just some of the names used at the time to refer to it.

Apart from the books published in recent years, there is not a rich documentation of Spanish, as was the case with other diseases, although there are many testimonies of survivors who recounted their symptoms and the empirical treatments they were given. Yet the Spanish flu struck all over the world, from Alaska to Africa, from Europe to New Zealand. In contrast, everything we are experiencing because of the COVID-19 of this astonishing 2020 has already entered history. In our global, hyper-connected society, millions of images have already been deposited in paper and multimedia archives around the world since this tragedy began. Certainly, much more than those relating to the other greatest tragedy in contemporary history, known as the Spanish Flu, the deadly, highly contagious influenza that caused more deaths than the two world wars put together.

Some historians have reaffirmed the close connection between the pandemic and the conflict: an initially circumscribed infection that was then transformed into a global emergency by the war. In fact, the "virus struck and quickly reached every corner of the earth thanks to the rapid exchange of men and means imposed by the conflict and shaped by the European colonisation of the globe. Influenza raced aboard trains, ships and the great communication routes opened up by nineteenth-century modernity. If the Black Death of the $14^{\text {th }}$ century had taken around seven years to infect Europe alone, the so-called Spanish Plague had infected the entire globe within a few months. It was a 'total' disease (today it would be called globalisation sickness), in an era of total conflict.
Worldwide, the 1918 Pandemic flu struck in three successive and closely spaced waves: the first, in the spring of 1918, the second in the autumn of the same year, and the third in the winter months between 1918 and 1919. The second wave, was the most lethal affecting most continents and persons including Chinese, Europeans and Americans. In fact, the wide circulation of the disease ensured that the viral agent mutated into a more lethal form, combining the ability to virulently attack the respiratory tract of man with high contagiousness. The disease spared the elderly or affected them less severely, while it raged against the young. This evidence seemed to point to the existence of a kind of immunisation, acquired by the generation that had experienced the influenza pandemic of 1889-90, which gave them a kind of natural defence against this disease.

The third wave, in the first half of 1919, was brought about by the great post-war movements: the return of veterans, the refugee movement, the resumption of trade. However, its capacity to infect and kill had started to decrease.

\section{Origin of Spanish flu pandemic}

It is not known exactly why and where the epidemic started, partly because at the beginning, during the spring phase, health authorities did not require reporting of influenza cases, as was the case in the US when the second wave broke out. Therefore, information on the beginnings of the different sub-epidemics is scarce and fragmentary [3].

All kinds of hypotheses were made about the origin of the pandemic: some claimed that it was a "simple flu", the effects of which had also been increased by the hundreds of unburied bodies on the battlefronts; others claimed that it was transmitted by parasites or the more common mosquitoes through infected blood; still others that the disease was actually 'trench fever', spread by lice that lurked in the soldiers' clothing [4].

Although the term of "virus" was known, many uncertainties remained about them even though tobacco mosaic virus had been isolated in the late 1800s, and no other virus was isolated until the discovery of the electron microscope in 1936 [5]. Thus, there were no definite answers, it was perceived that a bacterium was not the cause of the disease, but while a viral nature was suspected, the aetiology was far from clear. 
As the virus spread, advertisements for possible remedies appeared in parallel in the newspapers: from toothpaste, potions with more or less secret ingredients, microbe-killing cologne, simple disinfectants, a combination of quinine and castor oil, and pocket spittoons. However, the very high contagiousness and spread of the infection, against which all prophylactic measures were shattered, seemed to distinguish it clearly from all known bacterial infections, including pneumonic plague'.

The geographical origin of Spanish is a matter of dispute. Several epidemiologists have suggested that the Spanish flu virus, possibly originating in Kwangtung province (China), originally started in birds and then, through genetic modification, was transmitted to pigs, leading to swine flu. From pigs, it is thought to have been transferred to humans, becoming, after about half a century, a lethal strain for humans [6]. The drama of the conflict also masked the unusually high mortality rates of the new virus.

However, historian Alfred W. Crosby has argued that influenza originated in the US state of Kansas (Haskell County) as the starting point of the outbreak, although by the end of 1917 a first wave had already been recorded in at least 14 US military camps $[7,8]$.

It seems that the first outbreak occurred in some military camps in the United States, and that it arrived in Europe around the same time, but while in the countries at war the newspapers were censored and news of the mysterious disease came out quickly in Spain - where there was no war there was talk of the epidemic claiming so many victims. It was thought that the origin of the disease came from that country, and so the flu was given the name 'Spanish flu'.

The flu was killing its victims with incredible speed. Stories flourished in the United States about people waking up sick and dying on their way to work. The symptoms were gruesome: patients presented with fever and difficulty breathing. Due to the lack of oxygen, their faces turned a bluish color, expression of severe cyanosis. The hemorrhage filled the lungs with blood, causing vomiting and nose bleeds and eventually causing people to choke on their own fluids. Like so many flu-like illnesses before it, Spanish flu affected not only the very young and very old, but also healthy adults in their 20s and 40s. The main factor in the spread of the virus was, of course, the internation- al conflict, which was then in its final stages.

\section{The Spanish flu in Ferrara and in Italy}

In Italy, there was no simultaneous outbreak of Spanish flu throughout the country. The virus first arrived in a few Italian regions, in the north and south, and gripped the country in an epidemic grip. First, it arrived in Calabria, in Rosario, then in Campania, attacking Caserta, Naples and Salerno; then the provinces of Avellino and Benevento. From here it moved on to Sicily, attacking Catania, Caltanissetta, and Trapani. Finally, still to the south, it was the turn of Puglia. Then, as the epidemic thinned out in the south, it moved to central Italy (Latium, Abruzzo and Marche) and to the north, affecting Piedmont, Lombardy and Veneto.

Also, it has been suggested that coastal locations, urban centers, and areas with higher levels of connection via communication and transport networks endured higher mortality rates than remote, rural, and isolated areas (Svenn-Erik Mamelund, "Spanskeskyen i Norge 1918-1920: Diffusjon og demografiske konsekvenser" (master's degree thesis, University of Oslo, 1998). Phillips reached similar conclusions in explaining the variations in South Africa: Phillips, "Black October" (n. 4).

In Italy, as well as in many other countries, the Spanish flu pandemic hit in three successive and closely spaced waves: the first one appeared in spring-summer 1918 in a mild form, infected millions of people, disrupting daily activities among troops and civilians, but had a substantially low mortality rate.

The first cases of this unknown disease occurred in the ranks of the Regio Esercito (Royal Army) in April 1918, reaching a peak of infection between May and June [9]. Generally, the $1^{\text {st }}$ wave, despite the great morbidity, was mild and had a substantially short course. Some areas suffered from more severe forms, such as the Bassano area, where Red Cross Units were engaged day and night in transporting the sick on the front line by motorized ambulance. It is well known that the Disinfection Centres of the military health organisation are best placed to deal with the hygiene of clothing and soldiers on arrival and departure from the front [10].

Military Reports indicate the development of disease in the ranks of the Royal Army of a mild-tem- 
pered flu in April 1918, reaching the acme of contagion between May and June. The command of the VI Armata ( $6^{\text {th }}$ Army Corps) reported on May 26, 1918 that cases of flu had been occurring for several days among the troops of XII Corpo d'Armata (12 ${ }^{\text {th }}$ Army Corps). The symptoms were: $f e b-$ bri alte, cefalee, dolori lungo la rachide con fenomeni catarrali delle prime vie respiratorie e profondo senso di debolezza (high fevers, headaches, pain along the spine with catarrhal phenomena of the upper respiratory tract and a profound sense of weakness). The fever had a very short duration; the disease was in fact called Febbre dei Tre Giorni (fever of three days) [9].

In our country, the epidemic affected the army to a lesser extent than the civilian population; this perhaps was due to the intensive and complex sanitation work carried out by military health to prevent and treat communicable diseases [11]. However, Italian military personnel were also affected; they probably brought the virus back to our peninsula on their return from the front, thus causing the flu to spread through different routes in our peninsula [9].

The second wave scorched its way around the globe in the early autumn, with an often fatal course and was followed by another, less-severe wave early in 1919. The three waves circumnavigated the globe in a little less than a year.

Cutolo reports as Pierluigi Scolè's estimates: in October 1918, the pandemic infected $4 \%$ of the troops, causing one death every 11-12 affected. The hospitalization of the soldiers in military hospitals and the licenses caused the spread of the disease among the soldiers themselves and among civilians [9].

The epidemic hit the regions of Italy more or less strongly, with higher mortality rates for Lombardy, Lazio, Sardinia, Basilicata, lower for Veneto, Piedmont, Liguria instead [12].

A study relating to Bologna on the border with Ferrara, found that the epidemic impact, albeit being heavy, it was not particularly dramatic when compared with other situations [13].

Aspects relating to the provisions of the authorities and the spread of the "Spanish Influence" in the province of Ferrara have recently been discussed [12]. Some villages including Vigarano Mainarda, Codigoro, Ostellato, much less Berra e Copparo were more or less severely affected (Figure 1).

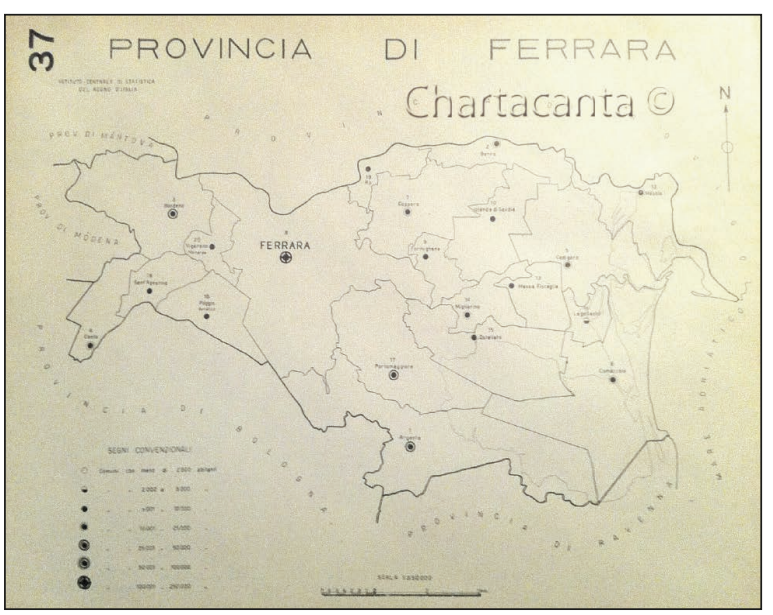

Figure 1 - Ferrara and its province in the first half of the $19^{\text {th }}$ century.

For a long time, medicine was in the dark about the causes of the epidemic. The health authorities began to claim that it was influenza no more and no less than the disease that Ferrara also experienced in the 19th century, but the population was not very willing to accept and believe them. Moreover, the newspapers continued to devote more space to the events of the war, at least until the beginning of October, by which time the Spanish Civil War had manifested itself in all its violence and was reaching its peak of intensity [14]. The initial symptoms were high fever, throat discomfort, dry cough, tiredness, headaches, pains in the limbs, conjunctivitis, but then they often got worse, and the patient began to have difficulty breathing, his nose bled, his skin turned purple, then came air hunger and often death [15]. In survivors, the debilitation lasted for about a week, and the physical consequences left on the people who had fallen ill also had repercussions on society, for example on the agricultural world, which risked being deprived of valuable labour at the most important time of the year. The general alarm began to rise. The second wave, the bad one, arrived in the autumn of the same year and lasted throughout the winter of 1919. Finally, the third wave began in December and lasted through the winter of 1919.

\section{The implementation of prophylaxis against Spanish flu in Ferrara}

In the months of Spagnola's arrival in Italy, the Ferrara population was confused and unclear: in 
some cases, people were advised to drink often, in others, to abstain; others suggested not to use tincture of iodine in any way, while others suggested adding two drops to water to disinfect the nasal mucous membranes and the throat [16-19]. A spontaneous question arises: did the citizens of Ferrara and its province realise that this unknown aetiological entity responsible for the "pandemic flu" was entering through the nasal and oropharyngeal mucous membranes, ahead of its time, as is now the case with respiratory viral infections?

Several Emilian towns and cities claimed many victims on the altar of pandemic flu. Vigarano Mainarda, in particular, a town of about 8,000 inhabitants located between two large cities in Emilia Romagna, Bologna and Modena, had the highest number of deaths $(+80 \%$ and a doubling of the number of women who died) followed by Codigoro ( $+77 \%$ and $90 \%$ of women) and Ostellato $(+74 \%$ and $94 \%$ of the women). The Spanish flu had less influence in the municipalities of Berra $(+30 \%)$ and Copparo (+23\%) (Figure 1).

In general, in Italy, keeping houses and public places clean, closing schools, disinfecting and avoiding masses or visits to cemeteries in the first days of November were among the main measures taken by the public authorities to try to limit the proliferation, even if it was not always easy to achieve them.

During the peak of the epidemic, the Prefect of Ferrara Orazio Giuffrida implemented measures that were considered by all to be extremely mild, only varying the opening hours of cinemas and pharmacies and prohibiting people from spitting on the ground $[19,20]$. Moreover, neither public places nor churches were ever closed, nor was the ringing of bells during funerals banned, although this request appeared in a newspaper and these mild measures did not fail to arouse strong criticism, also because the situation did not really seem to improve in the following days [20].

In Ferrara, precautions were not taken as in other cities. For example, the dead were left at home for three days, cinemas were not closed and there was no disinfection of shops and streets, unlike in large cities [21].

In general, the recommended rules for trying to avoid contagion do not differ much from those of today in times of COVID-19: "stay away from crowds of people, dust, confined places where the air is confined". Flee the "toxic ones", those who spit on the floor and on the handkerchief and sneeze and project droplets of saliva by talking. Since then therefore, the importance of droplets was understood. It should be noted that in this context in the United States of America, university lectures were held outdoors (Figure 2), which shows that droplets could be a source of infection, especially during gatherings, just as Pandemic of SARS-CoV-2 today.

Moreover, many of the rules in force against influenza were also adopted for Spanish flu, for example not kissing or caressing strangers and possibly not extending your hand in greeting, not joining companies, especially if they are made up of people from distant places. Definitely refrain from visiting the sick. "If you have a sore throat or a cold, do not kiss your family or use their personal belongings (...) Clean your hands and face several times a day, especially before eating and before going to bed, and when returning from public places and after touching the handles and doors of trains, trams, etc." ("To Avoid Influen$\left.\mathrm{za}^{\prime \prime}\right)$ [22].

Particular clinical aspects described in oral communications at the "Accademia delle Scienze di Ferrara" [23-25].

As a first survey approach, we found it interesting to investigate what the assessments of the epidemiological phenomenon were in the medical environment of Ferrara.

The epidemic had clearly appeared on the Ferrara scene in the autumn 1918 but the signs were already predictable in the previous months. We consulted the Repertorio generale dell'Accademia

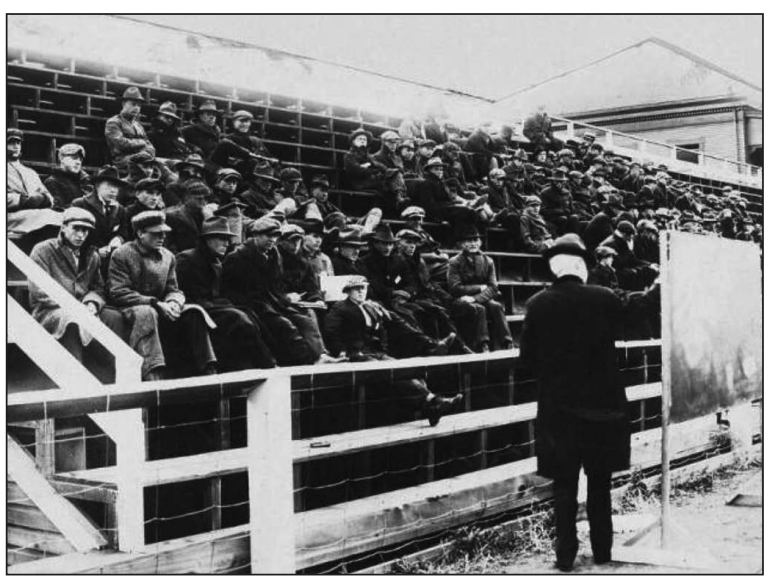

Figure 2 - Physics lecture, University of Montana, 1919. 
Table 1 - Ordinary sitting of Accademia delle Scienze of Ferrara of 12 April 1919 and 15 June 1920.

\begin{tabular}{|c|c|c|c|}
\hline Author & C. Minerbi & G. Tanfani & E. Casati \\
\hline $\begin{array}{l}\text { Symptoms } \\
\text { described } \\
\text { in Influenza } \\
\text { pandemic }\end{array}$ & $\begin{array}{l}\text { Analytical differentiation between } \\
\text { Influenza and vulgar catarrh of the } \\
\text { first airways. } \\
\text { Vulgar catarrh: swollen lymph } \\
\text { glands, inflammation of the } \\
\text { mucous membrane of the upper } \\
\text { airways acute catarrh of the nasal } \\
\text { sinuses (frontal and maxillary } \\
\text { sinuses) prosapalgia, albuminous } \\
\text { or mucopurulent discharge } \\
\text { Influenza: hyperaemia of } \\
\text { the jaws without phlogistic } \\
\text { oedema, neither adenopathy nor } \\
\text { mucopurulent secretion. } \\
\text { Bronchopneumonia, absence of } \\
\text { inflammatory coryza }\end{array}$ & $\begin{array}{l}\text { Description of nervous lesions by Influenza } \\
\text { Neurological Centre of Bari describes } \\
\text { "the peripheral lesions of unilateral } \\
\text { or asymmetrical neuritic type with } \\
\text { localisation at the root and not at the } \\
\text { distal extremity of the limb". } \\
\text { He also notes that there is a } \\
\text { correspondence between alterations } \\
\text { "of the thoracic limb" and "visceral } \\
\text { alterations of the thorax"; itself leading } \\
\text { him to think that it is a "vagotonic } \\
\text { reaction involving the same metameres". } \\
\text { Description of abdominal symptoms } \\
\text { (anorexia, vomiting, nausea, obstinate } \\
\text { constipation in which neuralgia } \\
\text { paraesthesia lasted for months or years) }\end{array}$ & $\begin{array}{l}\text { Description of cutaneous } \\
\text { symptoms } \\
\text { Empyema caused by } \\
\text { streptococci, frequent } \\
\text { furunculosis, pressure } \\
\text { wounds, suppurative } \\
\text { processes evolving } \\
\text { into septicaemia with } \\
\text { subsequent death. } \\
\text { According to the author, } \\
\text { this was due to the } \\
\text { "virulence of common } \\
\text { pyogenes" by the } \\
\text { influenza virus. }\end{array}$ \\
\hline
\end{tabular}

delle Scienze di Ferrara in search of reports on the subject in the years 1918-20.

From the proceedings of Accademia, there are unique descriptions (Table 1) of unusual pandemic influenza symptoms by the authors listed in the Table 1.

However, the speakers did not see an assessment of the Ferrara situation as serious.

\section{The Ferrarese setting in the development}

of the epidemic - The presence of military hospital

In order to assess the spread of the epidemic and the mortality rate in the city of Ferrara, it is necessary to consider particular conditions determined by the conflict taking place in the period.

In 1918-19, the city of Ferrara must have had approximately 100,000 inhabitants. The 1911 and 1921 censuses had in fact recorded 95,212 and 107,618 inhabitants, respectively. The able-bodied men were at the front. It is important to consider the presence of soldiers in the city with regard the period we analysed. "After Caporetto" the front hospitals moved to Ferrara, in the south of the Po river.

In the new hospital nearing completion located in Corso Giovecca / Rampari San Rocco, the possibility of creating a Red Cross Unit (Unità della Croce Rossa), the largest in Italy, was identified (Figures 3 and 4).

The two pavilions on either side of the entrance could accommodate 800 soldiers in the medical and surgical unit. After the retreat of Caporetto,

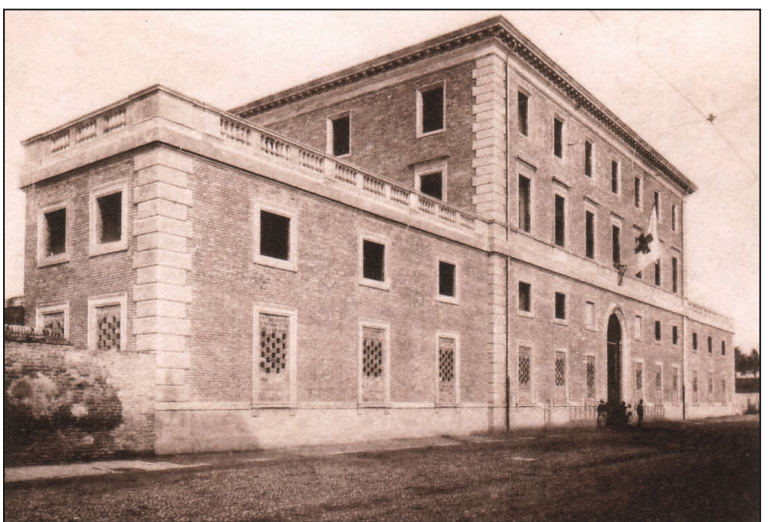

Figure 3 - Red Cross Hospital, 1915.

Ferrara per i soldati d'Italia, Bologna, Stabilimenti Poligrafici Riuniti, 1916.

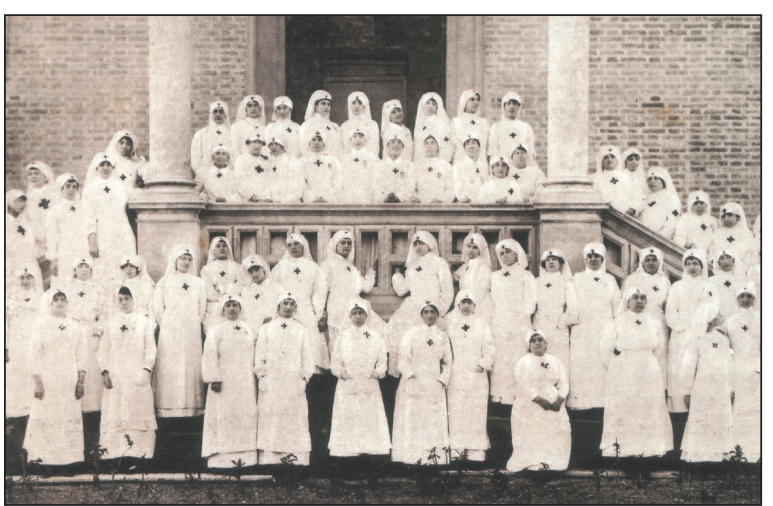

Figure 4 - Red Cross Hospital, Group of Dame in front of the Church.

Ferrara per i soldati d'Italia, Bologna, Stabilimenti Poligrafici Riuniti, 1916. 

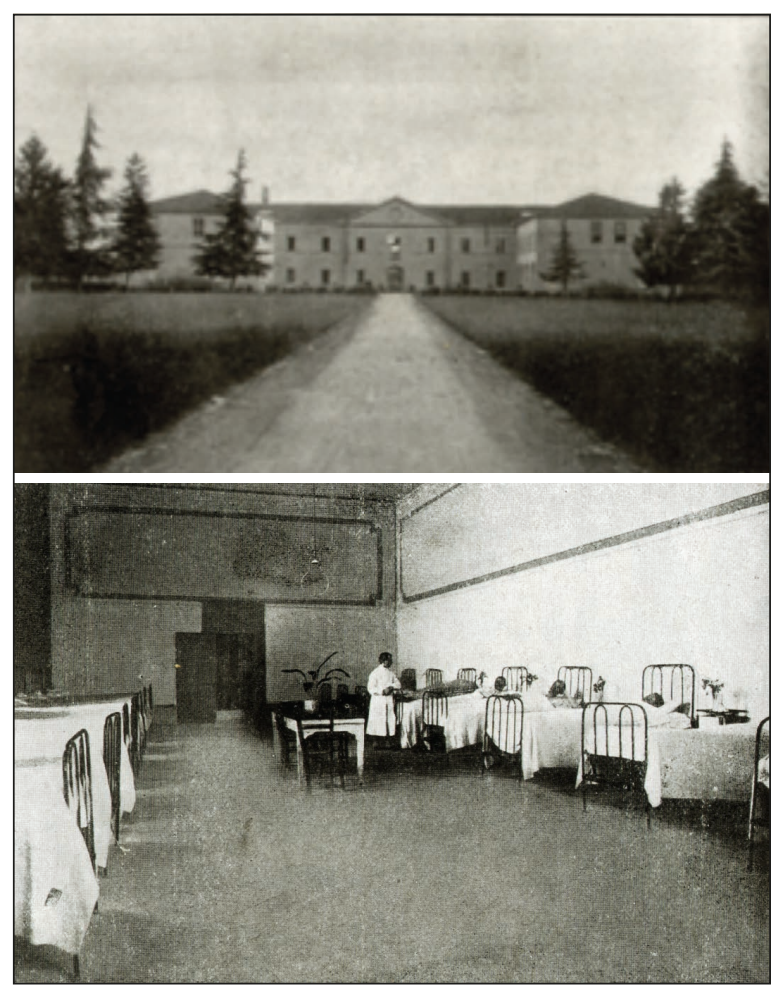

Figures 5 and 6 - Villa Seminario Hospital and its Ward. L'Ospedale Militare Speciale Neurologico per malati nervosi. Villa del Seminario, Aguscello (Ferrara), Ferrara, Prem. Tipografia Ferrariola, 1918.

the hospital Ospedale di Riserva of Ferrara under the Direzione di Sanità del Corpo d'Armata (Direction of Health of the Army Corps) of Bologna became Ospedale di Tappa.

On October 21 1918, the Administration of the Red Cross Hospital passed to the Military Health under the new name of Ospedale nuovo (New Hospital).

It was necessary, since Ferrara was the first evacuation hospital area, to set up other hospitals in the city's schools: "Scuole Bonati" in via Savonarola, "Scuole Guarini" in via Bellaria and "Scuole Varano". The movement of the hospitalized persons was 26,182 in 1918 and of 5,617 January - July 1919.

The "Villa Seminario" Military Neurological Hospital in Ferrara, now the Don Calabria "Città del Ragazzo" Institute, was the first Italian neurological hospital of the Great War for veterans from the front. It was an avant-garde pilot facility, designed for the specialized treatment of nervous disorders resulting from war, neurosis and psychosis caused

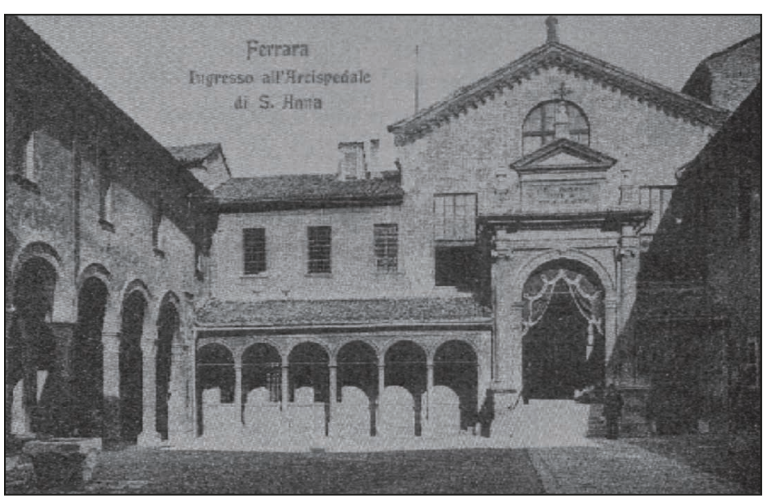

Figure 7 - Entrance of St. Anna Hospital at the beginning of the $20^{\text {th }}$ century.

by war or bombs, and could accommodate 200 soldiers in dormitories and 30 officers in reserved rooms (Figures 5 and 6) [26].

In addition to the military hospital, there was an important hospital and its branches in the city: the Arcispedale S. Anna, housed in the historic site in via Giovecca near the Estense Castle (Figure 7) and awaiting transfer, the Maternity Hospice in via Savonarola, the Asylum of Palazzo Tassoni in the Polesine di S. Antonio, now via della Ghiara, and the Lazzaretti branches, such as that of S. Maria della Consolazione in via Mortara $[27,28]$.

Data from the Register of the Dead from Ferrara city The Register of the Dead (Registro dei Morti) of the Municipality of Ferrara, present in the

Municipal Historical Archive, was consulted to recover useful data for the analysis of the incidence of the Spanish flu in Ferrara [29].

The series collects the burial registers in the Municipal Cemetery of Ferrara from 1900 to 1954 (deceased's name, paternity, place of birth, residence, age, profession, date, time, cause, place of death). The number of deaths in the years $1916(1,379)$, $1917(1,439), 1919(1,301), 1920(1,240)$ was first assessed.

The surplus in the year 1918 (2,618 deaths) compared to the average of the years taken into consideration is 1,279 units (Graphic 1).

It is a fact that can immediately give us the measure of the impact of the epidemic on the population. It does not give us the number of the infected, which is impossible to recover as there was no obligation to report any data, but it gives us the measure of lethality. 


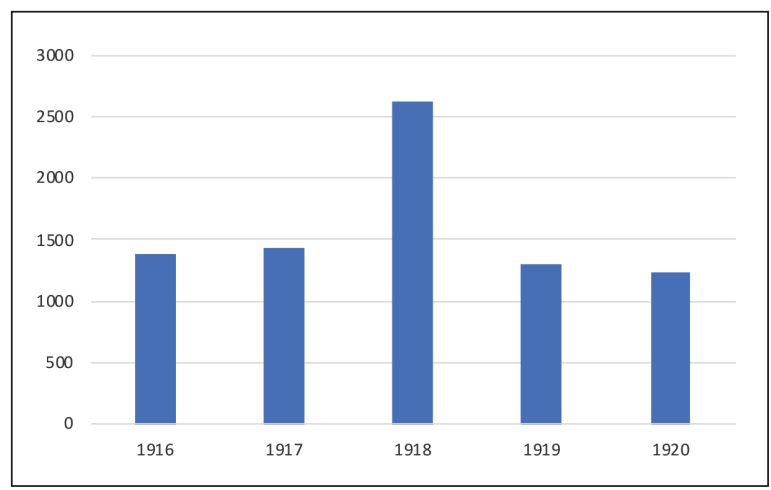

Graphic 1 - Number of Deaths (1916-1920), Libro dei Morti, Municipal Historical Archive of Ferrara.

The pattern of deaths in 1918 and 1919 shows a sharp increase from September 1918 with a peak in October with a rapid decline by the first quarter of 1919 and a return to normal in the following months (Graphic 2).

Cases of death from flu were extracted. The term "Influenza" was found by itself or associated:

a) influenza, febbre-influenza, influenza-bronco-polmonite, influenza-polmonite, influenza-emorragica, meningite-da-influenza;

b) grippe, broncopolmonite-grippe, polmonite-grippe, meningite-grippale;

c) febbre-spagnola, bronco-polmonite-spagnola, polmonite-influenza-spagnola.

The term "Spanish" was used for the first time in Ferrara as the cause of death for a soldier who died at the dawn on 22 September at the Hospital
Bellaria (Culatina Oliviero, 27 years old, 1385 Comp. Mitragl., born in Marcaria, MN).

In the period January 1918-June 1919, the number of deaths from flu, grippe or Spanish flu does not justify the increase in mortality (Graphic 3), so "not pure flu" data that affect mortality (other flu-related complications) were also taken into consideration. Therefore, in order to describe the distribution of deaths due to causes, it was essential to arrange for the grouping of diseases bearing in mind two fundamental aspects: the morbid forms and the anatomical site.

Seven main groups have been identified: bronchopneumonia; pneumonia (polmonite, polmonite cruposa); pleurisy (pleurite, pleuropolmonite); bronchitis (bronchite, catarro bronchiale); intestinal (catarro intestinale, enterite); flu (see above); infectious fevers (febbre infettiva, febbri intestinali, febbre infettiva polmonare).

Deaths from pulmonary tuberculosis, for which there is a slight increase, or from other frailties were not considered, unlike deaths from meningitis defined as grippe or influenza.

According to these criteria, 1,059 deaths were attributable to influenza or related causes in the period January-December 1918. This reflects in part the excess of deaths in the year 1918 of 1,279 over the average of the years 1916, 1917, 1919, 1920. In September-December 1918, 850 deaths were attributable to influenza or other diseases caused by the latter. The greatest number of the deaths is attributable to bronchopneumonia and pneumonia (Graphic 4).
Graphic 2 - Overall number of Deaths (January 1918 - December 1919), Libro dei Morti, Municipal Historical Archive of Ferrara.

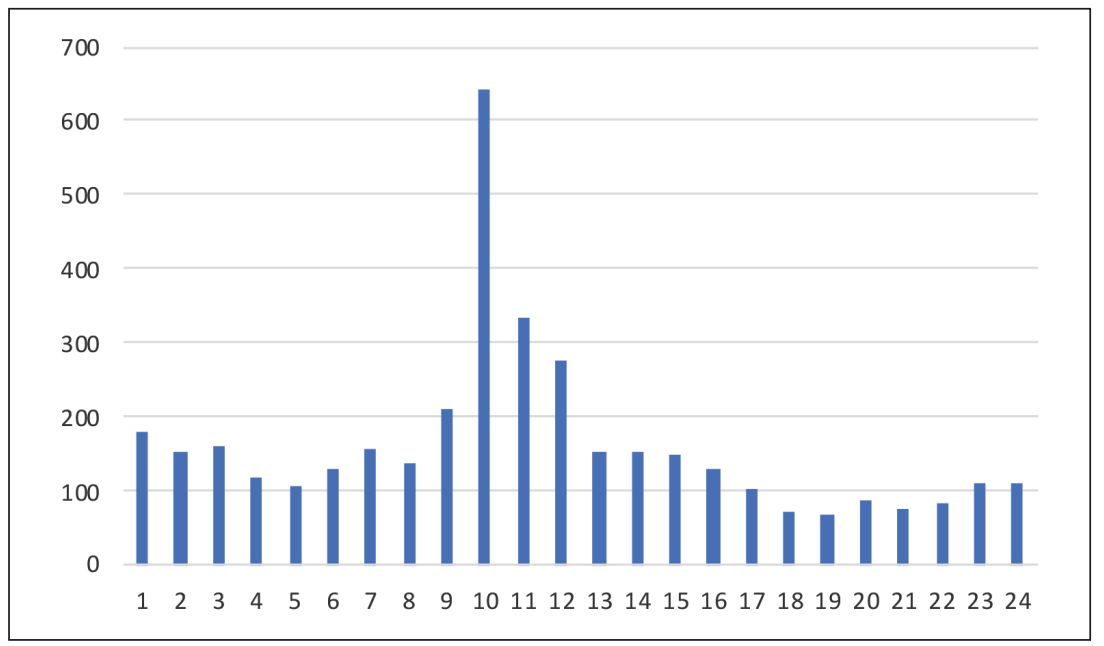


However, an increase in mortality from other infectious diseases such as ileus typhus, tuberculosis, malaria, intestinal (and some cases of smallpox up to January 2019) was observed in the period, covering the missing difference to arrive at the total deaths recorded [30].

There is an increase in septicemias, as noted by the Ferrara physicians in their reports.

As shown in Graphic 5, the period of the greatest mortality from all causes is the third quarter of the year 1918. From September (210 deaths) there is a peak in mortality in October (644 deaths), to then drop in November (335 deaths) and December (278 deaths) for a total of 1,467 deaths.

The months of January-March 1919 returned to

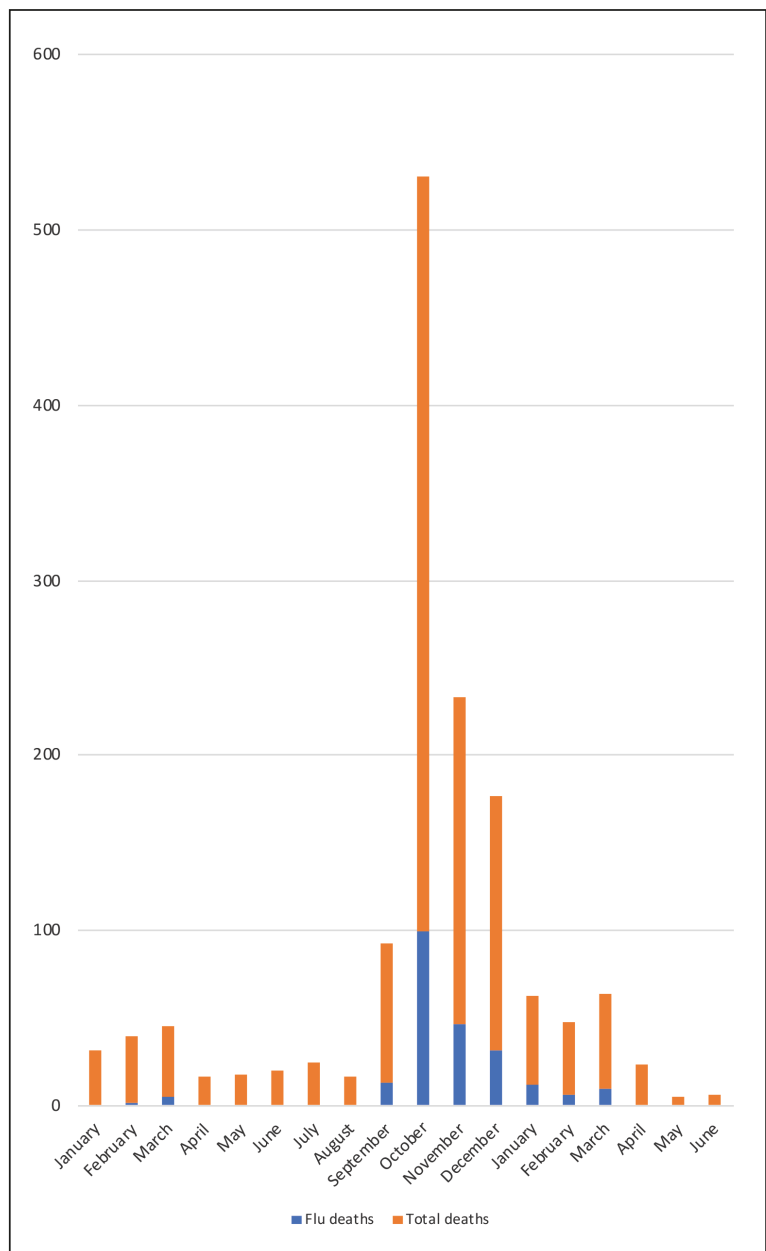

Graphic 3 - Distribution of deaths of Spanish flu (January 1918 - June 1920), Libro dei Morti, Municipal Historical Archive of Ferrara. values (about 150 deaths), with a slight increase in March, close to the same months of 1918 (181, 155, 161 deaths).

During the period, 309 deaths were counted in military hospitals due to flu.

The hospitals most affected were Villa Seminario with the first outbreak in mid-September, followed a week later by Bellaria and the Red Cross Unit starting in October (Graphic 6).

To the figure including soldiers, officials, Italian finance police and carabinieri must be added 30 refugees (profughi) who died from flu.

339 dead people present in Ferrara due to war correspond to $40 \%$ of the total deaths (850) due to the flu in the four-month period compared to the

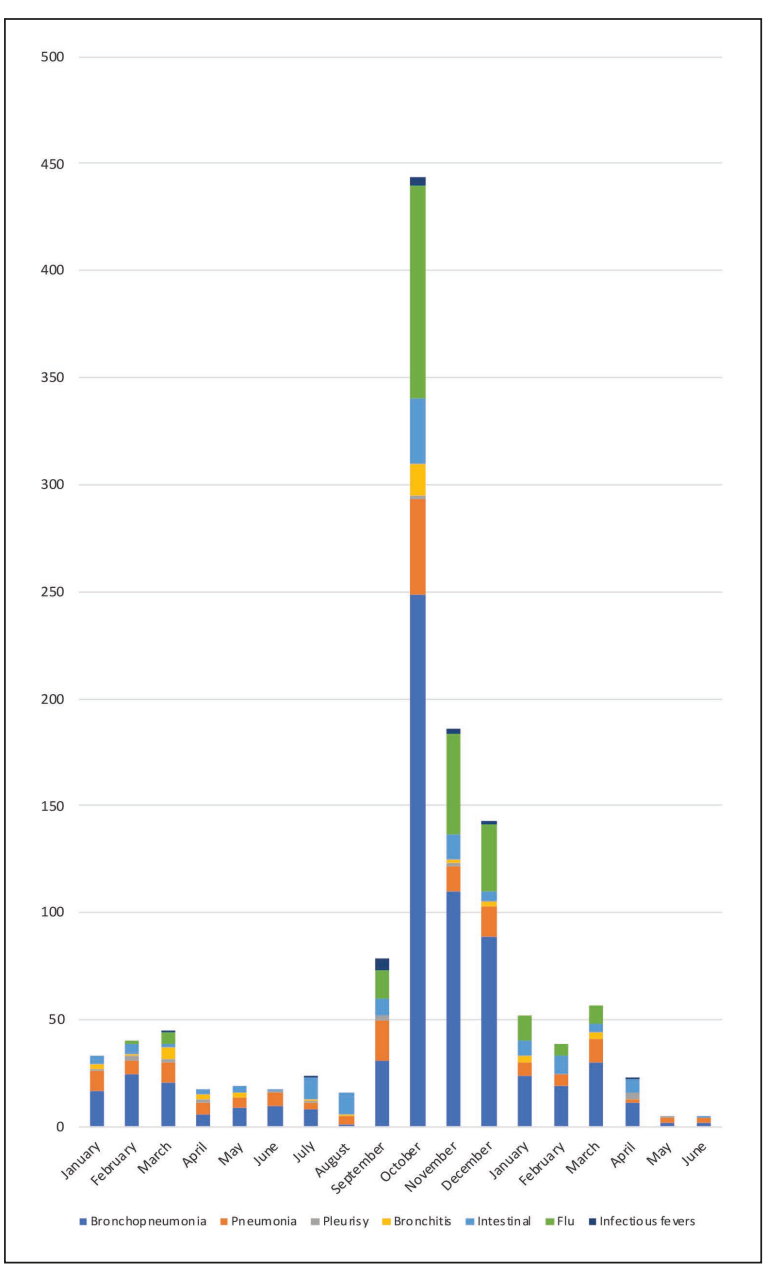

Graphic 4 - Distribution of deaths from causes attributable to Spanish flu (January 1918 - June 1920), Libro dei Morti, Municipal Historical Archive of Ferrara. 
Graphic 5 - Deaths from causes attributable to Spanish flu (January 1918 - June 1920), Libro dei Morti, Municipal Historical Archive of Ferrara.

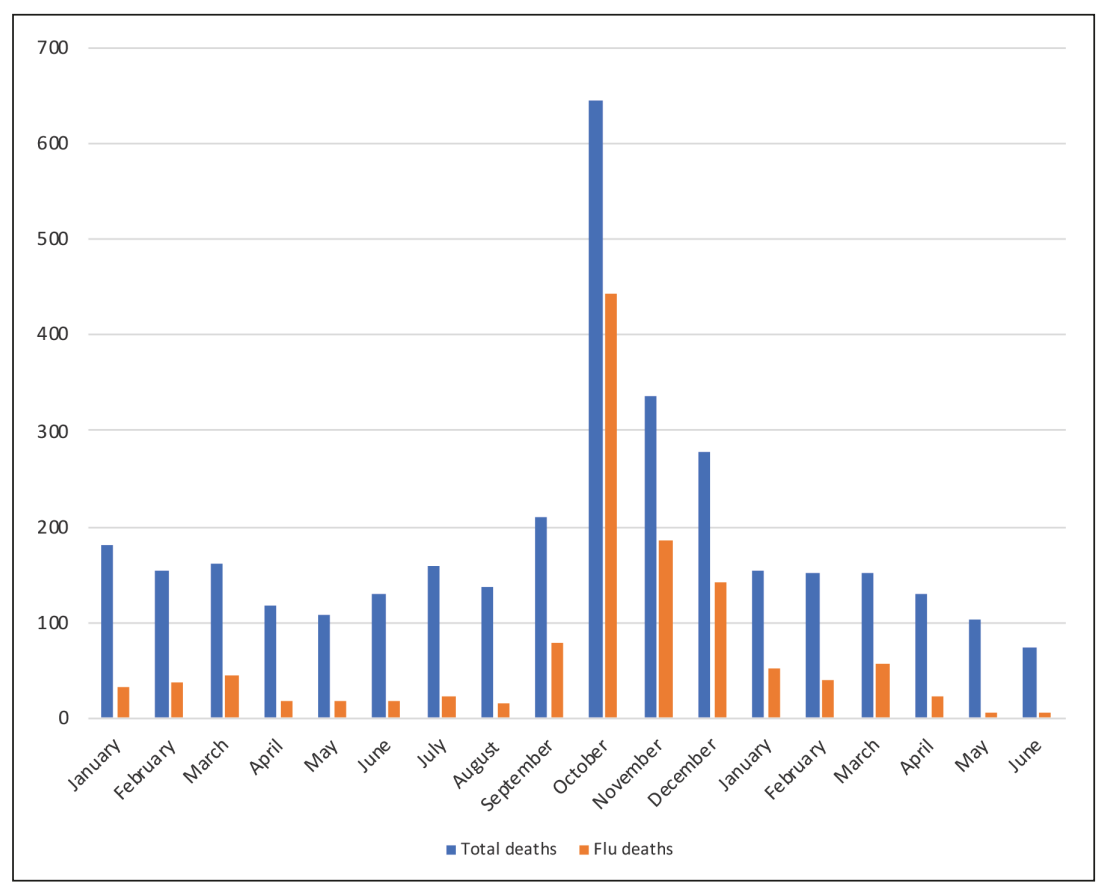

Graphic 6 - Deaths from causes attributable to spanish flu in the third quarter of 1918 in the Military Hospitals, Libro dei Morti, Municipal Historical Archive of Ferrara.

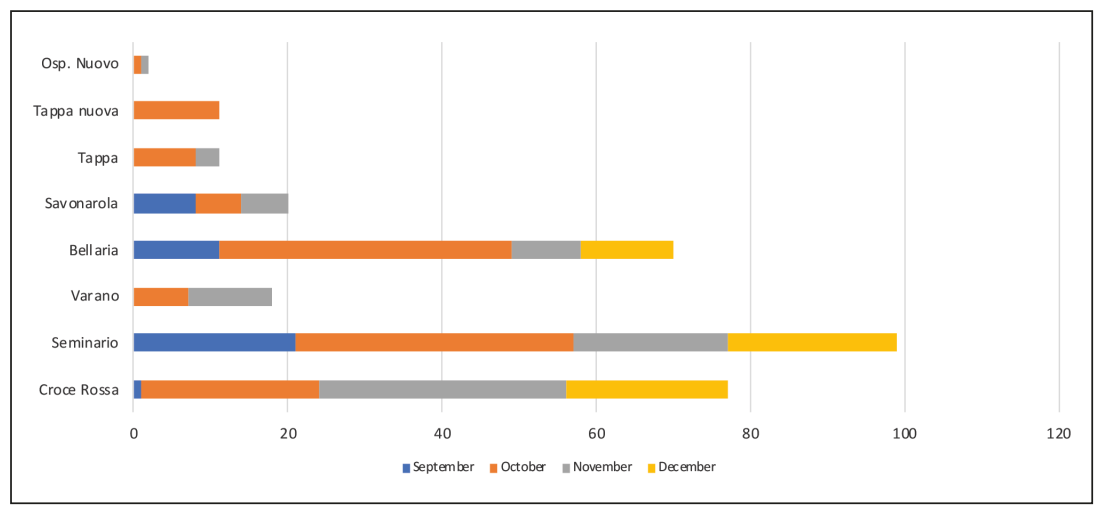

civilian population $(60 \%)$. Places where people are heavily concentrated such as military hospitals, the asylum - psychiatric hospital could facilitate the spread of contagion. Apart from numerous 'deaths from madness', only one outbreak was observed, in October, with 14 deaths from this cause in a few days and other sporadic cases. For those who died from flu in the third quarter, age (Graphic 7) and profession (Graphic 8) were assessed.

Mostly, young people and children under the age of 11 died.

On 28 September 1918, Guglielmo (6 years old) died of bronchopneumonia in the district of San Luca. On 30 September, a few hours later, his siblings Mirto and Nicoletta (aged 4 and 8 respectively), died of meningitis and bronchopneumonia as well. On 1 October, his 13-year-old sister Elena also died of right-hand pneumonia in hospital. The parents, Giorgio and Giuseppina, are not on the death list, the father was probably at the front, the mother, if infected, survived the disease.

Therefore, the number of deaths of children between the ages of 0 and 10, mainly males, is large. Doctors note that the elderly who had contracted 


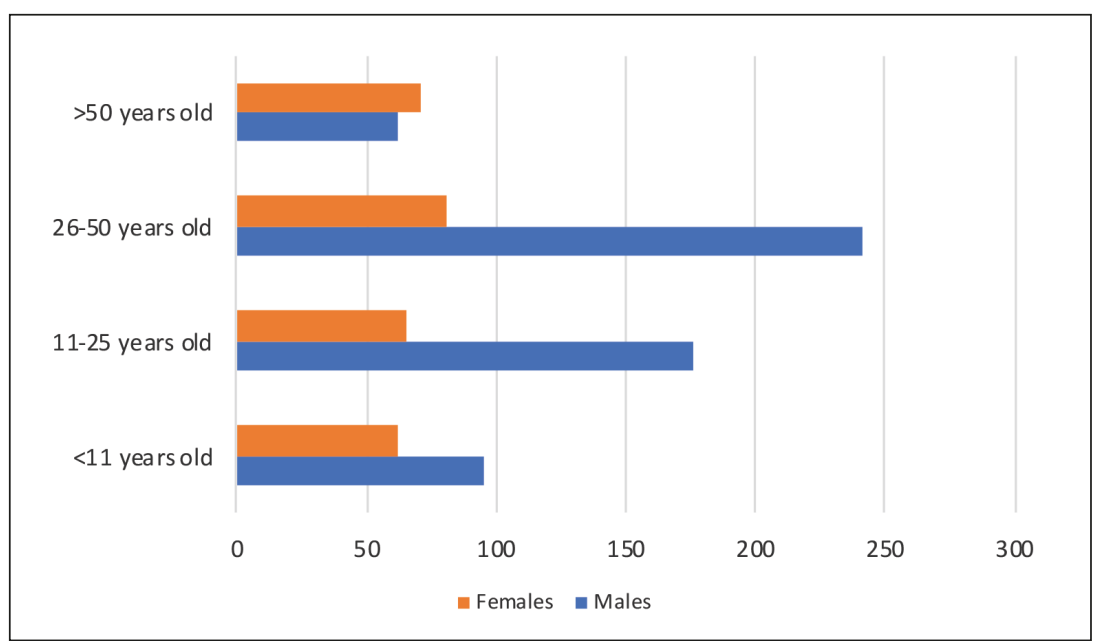

Graphic 7 - Distribution of deaths from causes attributable to spanish flu in the third quarter of 1918 by age, Libro dei Morti, Municipal Historical Archive of Ferrara.

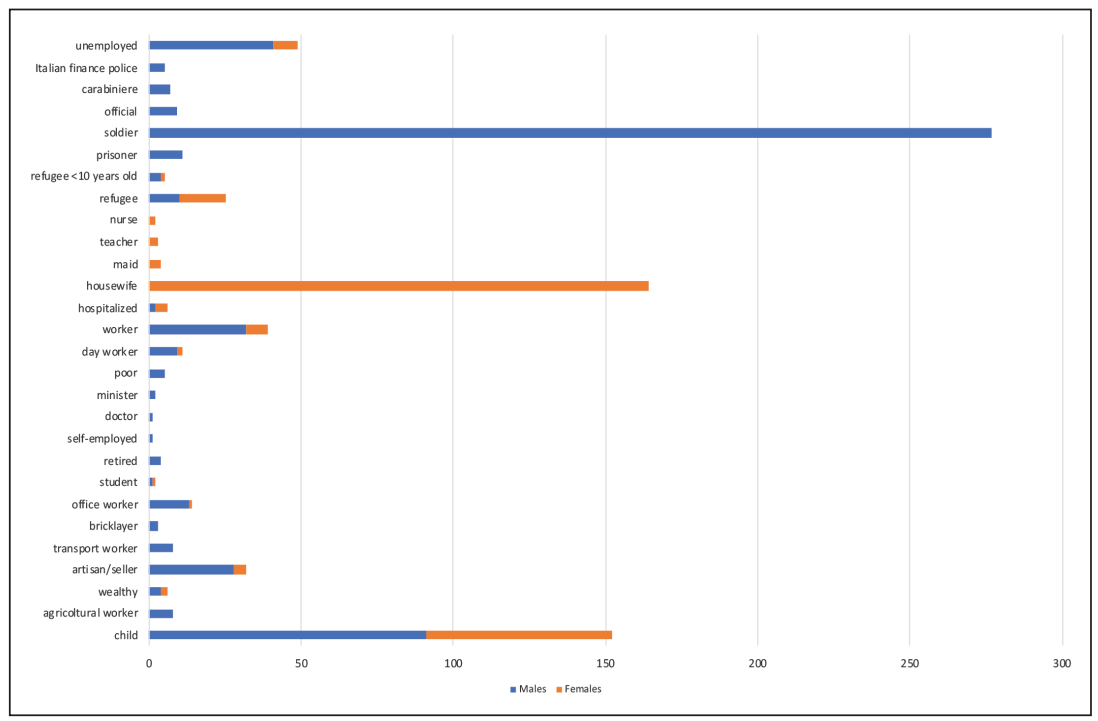

Graphic 8 - Distribution of deaths from causes attributable to spanish flu in the third quarter of 1918 by occupation and gender, Libro dei Morti, Municipal Historical Archive of Ferrara.

the flu in the late nineteenth century were immune to the infection.

The Spanish flu was an infection that affected both the poor mendicante, girovago (beggar, wanderer) and the rich possidente, benestante (landowner, wealthy).

By profession, the number of housewives was high among civilians, a very common status, even if in the period women opened up to new profession.

Among the deceased, even if in small numbers there were artisans, workers, day workers, office works, nurses, teachers.
Women were deputies to assist the sick in the family environment and therefore particularly exposed to contagion. They were classified as housewives at a very young age. This justifies the disproportion between males/females among the unemployed.

Among men there are professions with high public exposure, including transport and office workers. A doctor and two nurses died among civilian medical personnel.

Contrary to the national trend, the same proportion of civilian males and females who died due to flu is revealed in Ferrara [31]. 
The number of soldiers, prisoners and refugees who died for this cause is high, easily affected by the infections as they are often debilitated and in poor physical condition.

In conclusion, the real mortality of the pandemic could be between 50 and 100 million, but it seems unlikely that a truly accurate figure could ever be calculated. Despite the lack of accuracy, the scale of the mortality makes it undoubtedly one of the greatest epidemics in history, especially since these deaths occurred in a very short time, from early 1918 to, in some cases, much of 1920.

The "Spanish" flu has often been described as the "greatest medical holocaust in history". This is not only because of the very high number of deaths caused by the infection, but also and above all because most of the victims were young and in good health. According to one hypothesis put forward to explain this observation, the H1N1 strain responsible for this influenza must have hit the immune systems of these people (who are naïve to this virus) particularly hard, triggering a cytokine storm so intense that it flooded the lungs of those infected with fluid, obstructing their airways.

It is likely that the elderly and children were spared the most serious outcomes precisely because their immune systems are weaker and therefore less responsive to infection. In addition, that the elderly population was less affected as they had acquired some protective immunity from having mainly contracted the virus of another influenza epidemic that spread through the human population in the 1830s.

The curiosity of analysing the data, albeit limited to deaths, as there are no records of contagions, was to see if even in the case of the Spanish plague, although the city of Ferrara was not spared, it was less affected than other areas of the country.

In our previous research, Ferrara was partially spared by the plague in the late 1500s and 1630s $[32,33]$. Today, it seems that COVID-19 during the first wave struck less violently in this city. This may be related to different factors including the low population density of the area, which however cannot be a sufficient reason and the most fanciful hypotheses have been put forward (ANSA [35]).

In this study, we have found data that are not easy to analyze. The reference to deaths per number of inhabitants is distorted in particular by the fact that at the height of the epidemic Ferrara had become a hospital at the front, as it housed prisoners and refugees at the same time. The excess (1.278) of deaths in 1918 compared to the average of the previous and following two years (1.340) shows an increase in mortality of $95 \%$.

If we do not count military, prisoner and refugee deaths (370), the surplus of deaths is reduced to 908 , equal to an increase in mortality of $67 \%$ instead of $95 \%$.

In the years of the conflict, Ferrara had 100,000 inhabitants and thus 9 per 1,000 inhabitants compared to 8.8-9.4 per 1,000 inhabitants (national average reported by Tognotti [31].

The situation in the neighbouring city of Bologna was less serious: according to Sabbatani, 7,000 deaths were recorded in 1918, compared with $3,500-4,000$ per year in the 30-year period 19011930 [13].

Spanish flu mainly affected young people and soldiers in particular. Regarding soldiers in particular (Graph 8), deaths for influenza in this population were higher than in any other occupation; this was also due to the war and also to other infectious diseases that raged at the time such as typhoid fever. Studies in Italy indicate that women were particularly affected [31]. In fact, in Ferrara, males and females were affected in equal proportions.

The medical reports to the local academy do not reveal too much concern in the scientific community. The outbreaks seem to be mainly in military shelters and in family environments.

An epidemic that, in its most lethal form, when it reached Ferrara was gone in a matter of months.

\section{Funding}

None.

\section{Conflict of interest}

None.

\section{Acknowledgments}

The authors wish to thank the Directory of "Servizio Biblioteche e Archivi" (Library and Archive Service) of the Municipality of Ferrara for granting us permission to examine essential documents and are grateful to Donato Bragatto and "Associazione Culturale di Ricerche Storiche Pico Cavalieri" for giving us precious images. 


\section{REFERENCES}

[1] Winter, J L'influenza spagnola, in: La prima guerra mondiale, a cura di S. Audoin-Rouzeau, Becker J. Einaudi, Torino; 2010, 288.

[2] Barry JM, The Great Influenza: The Epic Story of the Greatest Plague in History. Viking Penguin; 2004, ISBN 978-0-670-89473-4.

[3] Wever PC, van Bergen L Death from 1918 pandemic influenza during the First World War: a perspective from personal and anecdotal evidence. Influenza Other Respir Viruses. 2014; 8 (5), 538-46.

[4] Vicentini CB, Manfredini S, Contini C. Ancient Treatment for Lice: A Source of Suggestions for Carriers of Other Infectious Diseases? Infez Med. 2018; 26 (2), 181-92.

[5] Wendell Stanley, Nobel Prize; MLA style: Wendell M. Stanley - Facts. NobelPrize.org. Nobel Media AB 2021. Mon. 29 Mar 2021.

<https: / / www.nobelprize.org/prizes / chemistry/1946/stanley/facts/>).

[6] Shortridge F.K. The 1918 "Spanish" flu: pearls from swine. Nat Med. 1999; 5, 4, 384-85.

[7] Barry J., The site of origin of the 1918 influenza pandemic and its public health implications. J Translat Med. 2004; 2, 3, DOI:10.1186/1479-5876-2-3, PMC 340389, PMID 14733617.

[8] Mills CR, Robins JM and Lipsitch M. Transmissibility of 1918 pandemic influenza. Nature. 2004; 432, n. 7019, 904-6, DOI:10.1038/nature03063.

[9] Cutolo F L'influenza Spagnola nel Regio Esercito (1918-1919). Annali, Museo Storico Italiano della Guerra 2019; (27), 33-60.

[10] Red Cross volunteers and the Spanish flu pandemic, www.redcross.org.uk [URL accessed 15 May 2019].

[11] Kolata G, Flu. The Story of the Great Influenza Pandemic of 1918 and the Search for the Virus That Caused It. Farrari, Straus and Giroux, 1999; 330.

[12] Guarnieri D La febbre Spagnola in provincia di Ferrara, In Ferrariae Decus Studi-Ricerche 2019; (34), 111-25.

[13] Sabbatani S, Fiorino S La pandemia influenzale "spagnola". Infez Med. 2007; (4), 272-85.

[14] Vicentini CB, Guidi E, Lupi S, Maritati M, Manfredini S, Contini C. L'influenza nelle ondate epidemiche del XIX secolo. Infez Med. 2015; 23 (4), 374-89.

[15] Jordan EO The Influenza epidemic of 1918, J Am Med Ass. 1927; 89, (19). DOI:10.1001/jama.1927.9269019 0001013. [URL accessed 24 march 2020].

[16] L'epidemia in provincia, Gazzetta ferrarese, 12 October 1918 .

[17] La febbre spagnola. Norme di prevenzione e di cura, Gazzetta ferrarese, 5 October 1918.
[18] Giuffrida O, et al. Memoria Web - Trimestrale dell'Archivio storico del Senato della Repubblica - n. 30 (Nuova Serie), giugno 2020.

[19] I provvedimenti contro la forma influenza, Gazzetta ferrarese, 10 October 1918.

[20] Il suono delle campane, La Rivista, 24 October 1918. [21] Per la tutela della salute pubblica, Gazzetta ferrarese, 20 October 1918.

[22] Per evitare l'influenza, La Provincia di Ferrara, 8-9 October 1918.

[23] Minerbi C Su alcuni criteri di semiologia fisica per la diagnosi differenziale tra influenza e catarro infettivo volgare delle vie aeree. Accademia delle Scienze di Ferrara, Seduta ordinaria del 12 Aprile 1919, Vol. Atti a.a. 1918-19, anno XCIII, 35-7.

[24] Casati E Alcune considerazioni sulla recente pandemia, Accademia delle Scienze di Ferrara, Seduta ordinaria del 12 Aprile 1919, Vol. Atti a.a. 1918-19, anno XCIII, 38-9. [25] Tanfani G L Lesioni nervose da influenza, Accademia delle Scienze di Ferrara, Seduta del 15 giugno 1920, Vol Atti 1919-20, a.a. XCIV, pag. XXXV.

[26] Bragatto D L'Ospedale Militare di Riserva per malati nervosi "Villa Seminario" di Ferrara, in: 1915-1918: Guerra e Sanità militare. Un confronto con i giorni nostri (a cura di Lorenzo Cappellari ed Enrico Trevisani). M. Tosi, Ferrara; 2007.

[27] The Maternity hospice, founded by Lucrezia d'Este under the title S. Maria del Soccorso, was transferred in 1924 to the S. Anna Hospital from the former convent in via Savonarola. (Chinarelli G. L'Arcispedale Sant'Anna di Ferrara. Fondazione Orlando Arlotti, Ferrara; 2003, p. 170).

[28] Chinarelli G. L'Arcispedale Sant'Anna di Ferrara. Fondazione Orlando Arlotti, Ferrara; 2003, p. 175.

[29] Registri dei Morti (1800-1954), Municipal Historical Archive; years 1916-1920.

[30] Smallpox arrived in Italy due to the passage of Romanian prisoners.

[31] Tognotti E, La Spagnola in Italia. Franco Angeli, Milano; 2015.

[32] Vicentini CB, Contini C Control measures of a 400-year-old plague epidemic: an example of past efficiency at controlling disease and similarities with current epidemics. Infez Med. 2020; 28 (4), 621-33.

[33] Vicentini CB, Manfredini S, Mares D, et al. Empirical "integrated disease management" in Ferrara during the Italian plague (1629-1631). Parasit Intern. 2020; 75, (1), 102046.

[34] https:/ / www.ansa.it/emiliaromagna/notizie/ 2020/03/30/caso-ferrara-allo-studio-resistente-al-contagio_de0f38bf-4b7b-41a8-bb1b-d5f301b73da2.html. 